\title{
Tipps und Tricks: Gebrochene proximale Femurnägel herausziehen
}

$\square$ Dankward Höntzsch

Das distale Fragment eines gebrochenen proximalen Femurnagels herauszuholen, ist immer wieder schwierig.

Ein Trick, der versucht werden kann, ist: Man nimmt eine Schanz'sche Schraube, entweder $4,5 \mathrm{~mm}$ oder $5 \mathrm{~mm}$ in einem Dreibackenfutter. Diese wird dann in die Kanülierung eingedreht. Bei Titannägeln geht das Eindrehen leichter als in alten
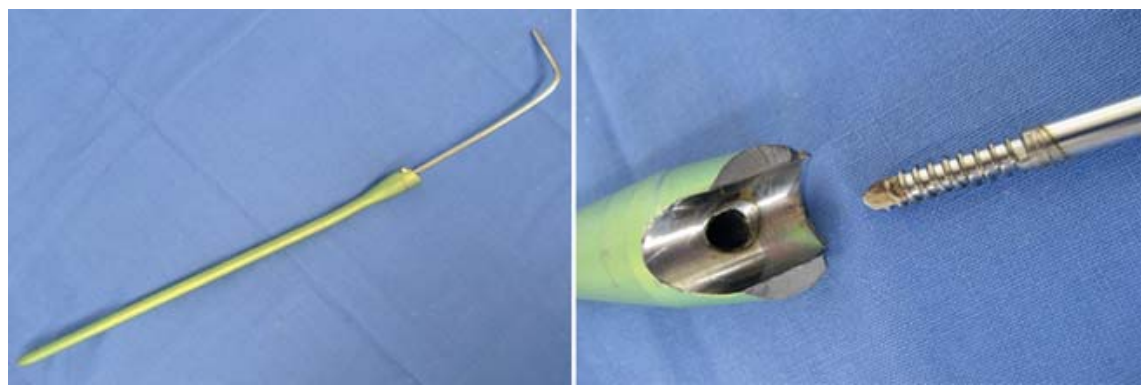
Stahlnägeln. Aber in beiden Nagelsorten hat das in der Hand des Autors schon öfters funktioniert. 